\title{
АНАЛІЗ ПЕРЕКЛАДУ МОВНИХ ЗАСОБІВ ВЕРБАЛІЗАЦІЇ ЕМОЦІЙ В АНГЛО-УКРАЇНСЬКОМУ ПЕРЕКЛАДІ РОМАНУ ДЖ. ФАУЛЗА «КОЛЕКЦІОНЕР»
}

\begin{abstract}
Анотація. Статтю присвячено дослідженню мовних засобів вербалізації емоцій у художньому дискурсі та питанню відтворення цих засобів у перекладі художньої літератури з англійської мови на українську. Встановлено, що емотивність $є$ не лише семантичною, але й інтерлінгвальною та прагматичною категорією, яка реалізуеться на всіх рівнях мови - фонологічному, морфологічному, лексико-семантичному та синтаксичному. Проведено аналіз відтворення українською мовою вербалізаторів емоцій та можливих труднощів передачі емоційного змісту тексту з метою встановлення найбільш вдалих перекладацьких трансформацій під час перекладу художнього тексту. Основна увага приділяеться лексичним і синтаксичним засобам вербалізації емоцій - вигукам і вигуковим конструкціям, лайливим словам, еліпсам, повторам і номінативним реченням, що містяться у дискурсі героїв роману.
\end{abstract}

Ключові слова: емотивність, емотивна лексика, художній переклад, лінгвістика емоцій, перекладацькі трансформації.

Kukhta Olha, Tsiokh Larysa

Lviv Polytechnic National University

\section{ANALYSIS OF THE REPRODUCTION OF EMOTIONS' EXPRESSION IN THE ENGLISH- UKRAINIAN TRANSLATION OF J. FOWLES' NOVEL “THE COLLECTOR”}

Summary. The article is devoted to the study of linguistic means of emotion' verbalization in literary discourse and the use of these means in the translation of fiction from English into Ukrainian. One of the main characteristics of fiction is the presence of emotional content that evokes a specific psychological reaction in the reader. Difficulties in translating an emotive language are explained by the complexity of the object of study. It has been suggested that the lack of a unified theory of emotions, universal classification of emotions, and the ambiguity of their denotation have a negative impact on the process of analysis of their linguistic reflection. The article establishes that emotivity is not only semantic but also interlingual and pragmatic category, which has an immanent linguistic property to express psychological states and human experiences and is realized at all levels of language - phonological, morphological, lexico-semantical, and syntactical, each of which has its own system of expression. An analysis of the reproduction of verbalizers of emotions into the Ukrainian language and possible difficulties in conveying the emotional content in the translation of a literary text on the material of J. Fowles' "The Collector" was carried out in order to establish the most effective translational transformations. The main focus of the analysis is on the lexical and syntactic means of verbalizing emotions: interjections, vulgar and obscene language, ellipses, repetitions, and nominative sentences that occur in the discourse of characters. It has been established that the translation of means of verbalization of emotions requires the selection of equivalents that can achieve a pragmatic effect and convey a full range of emotions, taking into account the peculiarities of the mental phenomenon of emotions and the specifics of their expression in a particular culture. The problem of demarcation of emotive, evaluative and expressive categories is vital for stylistic analysis, as their impact on the reader may be different and requires research according to the context and situation.

Keywords: emotivity, emotive lexis, literary translation, lexicon of emotions, translational transformations.

$\Pi$ остановка проблеми. Перекладацькі стратегії, що регулюють процес перекладу тісно пов'язані з ідентичністю відтворюваної інфрормації і залежать від типу тексту, що перекладаеться. Завдання перекладу художнього тексту має свої специфічні особливості. Одна 3 основних характеристик, що відрізняють художню літературу від будь-яких інших літературних напрямів, - наявність емоційного змісту. Важливою фрункцією емотивності художнього тексту є здійснення прагматичного впливу на читача, яка полягає в тому, щоб викликати у читача певну психологічну реакцію для яскравішої та чіткішої передачі задуму автора художнього твору. Складність, розмитість і різноманіття емоційних концептів, а також необхідність врахування норм мови та мовленнєвої традиції культури мови реципіента неминуче позначаються на вербалізації емоцій, що робить переклад художнього тексту одним із найскладніших і найбільш схильних до «втрат» видів перекладацької діяльності. У зв'язку з цим категорія емотивності займає одне з провідних місць у сфері сучасного перекладознавства і виникає необхідність визначення способів перекладу, які б уможливлювали досягнення адекватності при відтворенні неоднозначних елементів оригіналу.

Аналіз останніх досліджень і публікацій. Перехід від системно-структурної до антропоцентричної парадигми в гуманітарних науках сприяв зосередженню лінгвістів на засобах вербалізації та принципах актуалізації та фрункціонування емоцій у мові. Вивчення цих питань знаходить свое відображення у працях В. фрон Гумбольдта, Ш. Баллі, В. В. Виноградова, О. О. Потебні, В. І. Шаховського, О. В. Александрової, О. Е. Філімонової, Л. Г. Бабенко, А. Вежбіцької, I. Арнольд та ін. Серед основних напрямів досліджень емоцій у тексті варто виділити виявлення різнорівневих лінгвістичних засобів репрезентації категорії емотивності, вивчення критеріїв емотивності мови та її знаків і визна- 
чення основних емотивних прагматичних установок тексту.

Виділення не вирішених раніше частин загальної проблеми. Всупереч великій кількості досліджень у галузі лінгвістики емоцій та визнання значущості емоційного чинника для вивчення мови, все ще відзначається недостатня розробленість основних проблем даного напряму. Одним із найбільш спірних питань є трактування та вживання таких суміжних понять як «емоційність» та «емотивність». Про недостатність вивчення емотивної лексики також свідчать наявність різноманітних підходів і суперечливих поглядів щодо класифрікації емотивної лексики та співвідношення категорії емотивності 3 категоріями експресивності й оцінності, а також невизначеність компонентів лексичного значення слова, які формують емотивність мовної одиниці. Крім того, в українському перекладознавстві ще недостатньо висвітлена проблема національно-культурної специфріки емоційного вираження і застосування трансформацій у процесі перекладу засобів вербалізації емоцій.

Мета статті. Головною метою ціеї роботи $\epsilon$ виявлення та аналіз емотивних компонентів і засобів вербалізації емоцій в англо-українському перекладі роману Дж. Фаулза «Колекціонер».

Виклад основного матеріалу. Сучасна лінгвістика все частіше звертається до вивчення лінгвістичної репрезентації внутрішнього світу людини, особливо ̈̈ емоційної сорери. Оскільки емоції утворення особистісні та пов'язані 3 когнітивними процесами, мовне вираження емоцій не $є$ відображенням безпосередньої предметної дійсності, але дає уявлення про суб'єктивне ставлення людини до неї [14, с. 32]. Текстолінгвістика давно звернула увагу мовознавців на проблему емоцій у тексті. Здатність текстів хвилювати, змушувати переживати зміст, приносити задоволення завжди визнавалася їхньою невіднятною якістю. Емотивність тексту як мовне втілення емоційності і сьогодні залишається однією з найневизначеніших текстових характеристик. Формування лінгвістичних поглядів на цю проблему багато в чому обумовлено загальнонауковою традицією протиставляти чуттеве раціональному в природі людини. Ще 3 часів античності (Аристотель, Платон) емоції пов'язували зі станами тілесного дисбалансу, протиставляючи розуму. У зв'язку з цим емотивність тривалий час розглядалася як суб'єктивне за своєю природою явище, що суперечить принципу раціональності, інформативності, і яке не підлягає лінгвістичному опису [6, с. 117].

Деякі дослідники, наприклад А. Вежбіцька [4], В. Шаховський [12], О. Філімонова [14] стали виділяти окремий напрямок - лінгвістику емоцій, яка характеризуеться переходом від дослідження окремих емоцій та семантичного мовного простору до, зокрема, дослідження вираження, вербалізації та комунікації.

На думку Л. Г. Бабенко, труднощі вивчення мови емоцій пояснюються складністю та унікальністю самого об'єкта дослідження. Емоціі пов'язані лише 3 людиною та становлять із нею нерозривну єдність. Їм притаманний подвійний спосіб відображення у мові. По-перше, вони проявляються в мові як емоційний супровід, емоційне забарвлення, що виникає в результаті проникнення в мову емоційного стану мовця у вигляді емоційних оцінок. По-друге, емоції відображаються мовними знаками як об'єктивно існуюча реальність [3, с. 11].

Як у лінгвістиці, так і в психології та фрілоcoфpiï було здійснено багато спроб класифрікації емоцій. Науковці погоджуються, що деякі окремі емоції є універсальними, загальнокультурними феноменами, а кодування i декодування ряду емоційних виразів однакові для людей усього світу, в незалежності від їхньої культури, мови чи освітнього рівня [5, с. 95]. Водночас психологи відзначають, що емоційний вокабуляр є етноспецифрічним і має свої відмінності в різних мовних культурах. Окрім універсальних базових емоцій варто виділити також соціалізовані (в іншій термінології - моральні чи естетичні) емоції, які є продуктом соціального розвитку та виховання [12, с. 18]. Складність створення подібної класифрікації полягає і в тому, що часто та сама емоція позначається різними словами, а те чи інше мовне позначення може виявитися лише позначенням ступеня інтенсивності емоції, що вже має свою назву в мові (наприклад, радість-захват-ейфорія). Відсутність єдиної теорії, різноманітність класифікацій, виконаних на різних підставах і неоднозначність позначення емоцій створюють додаткові труднощі для лінгвістів, які звертаються до проблем емощійної варіативності мовлення.

Вчені по-різному оцінюють емотивність. У той час як одні вчені використовують поняття «емотивність» та «емощійність» як синоніми, інші ж, навпаки, чітко розмежовують дані визначення. Основна відмінність у тому, що «емоційність» належить до психологічної категорії, а «емотивність» - до лінгвістичної [11, с. 55]. Іншими словами, емотивність є мовним вираженням (або відображенням) емоційності. Моделюючи процеси подання емоцій у мові, В. І. Шаховський пропонуе вважати, що емотивність як лінгвістична категорія представляе іманентну властивість мови висловлювати психологічні (емоційні) стани та переживання людини та реалізується на всіх рівнях мови: фонологічному, морфологічному, лексико-семантичному та синтаксичному [12, с. 69].

Існують різні підходи до розподілу та опису емоційних лексичних одиниць, що зумовлено відмінностями в трактуванні емотивності і місцем емотивного компонента в семантичній структурі слова. Згідно з лінгвістичними дослідженнями В. I. Шаховського, лексичний склад мови включає два види слів - емотивну лексику та лексику емоцій $[11$, с. 56]. Ці категорії прийнято розрізняти відповідно до того, чи міститься емотивний компонент у їхньому смисловому значенні. Лексика емоцій лише називає або описує емоцією і за своєю семантикою є нейтральною. Розвиваючи думку В. І. Шаховського, Л. Г. Бабенко відносить до емотивної лексики сукупність слів, що за своєю семантикою обов'язково містять емотивний компонент (афективи, що виражають емоційний стан мовця: слова зниженого стилістичного тону, вигуки й вигукові конструкції) у статусі значення, і конотативи, у яких емотивні семи супроводжують основне логіко-предметне значення [3, с. 16]. 
Оскільки суворий поділ смислового та емоційного у мові неможливий, засоби актуалізації категорії емотивності нерідко переплітаються 3 категоріями оцінності та експресивності [2, с. 162]. У той час як багато авторів розглядають ці поняття недиференційовано, більш переконливою видаеться точка зору дослідників, які розуміють експресію як посилення дієвої сили мовної одиниці, а оцінність, як вияв позитивного або негативного судження про предмет. Проблема розмежування цих категорій мае значення для цілей стилістичного аналізу, оскільки їх вплив на читача може бути різним і потребуе дослідження в умовах контексту та ситуащії.

Для вивчення засобів вербалізації емоцій певною мовою найкраще підходить художній текст, невіддільною частиною якого $е$ описи людських почуттів, переживань та емоційних станів. Одним 3 основних завдань художнього перекладу є максимально повна передача емоційної та естетичної інформації засобами мови перекладу 3 метою створення того ж прагматичного впливу на реципіента, що і вихідний текст оригіналу [9, с. 28]. Аналіз перекладів свідчить про те, що для цього типу текстів характерні відхилення від максимальної точної передачі змісту для забезпечення якості та художності $[7$, с. 78]. Подібні відхилення, що зберігають художню цінність перекладу, відбуваються під час перекладацьких трансформацій. У таких випадках інформативна складова перекладу принципово відрізняеться від оригіналу, але при цьому емоційне сприйняття залишається незмінним.

У лексичному репертуарі емотивності найбільш репрезентативну роль виконують вигуки та вигукові конструкції. У більшості випадків вони зустрічаються не в непрямих описах емоційного стану, а в дискурсі персонажів, який виконуе комунікативно-естетичну функцію в художній літературі і є особливо виразним засобом передачі живої, природної мови. У вигуках зосереджено всі типові риси, що відрізняють емоційну лексику: синтаксична фракультативність, відсутність синтаксичних зв'язків з іншими частинами речення, семантична іррадіація, яка полягає в тому, що присутність хоча б одного емоційного слова надае емоційності всьому висловленню [2, с. 106]. Для адекватного перекладу необхідно враховувати контекст, національні особливості походження та вживання вигуку та інтонацію, яка багато в чому визначае зміст висловлювання.

Розглянемо кілька прикладів вигукових одиниць, які найбільш вдало демонструють особливості реалізації емотивної лексики у романі «Колекціонер» Дж. Фаулза та його перекладу з англійської мови на українську.

Значна кількість емоційних слів, зокрема вигуків, сигналізують про емоцію у загальному вигляді, навіть не вказуючи на її позитивний чи негативний характер. Особливо багатозначним $\epsilon$ первинний емоційний вигук $\mathrm{Oh}$, який може виражати цілу гаму емоцій і почуттів, а його визначення можливе лише в контексті. У першому випадку використаний вигук відтворюе не лише функціонально-прагматичне забарвлення, але й аналогічну орфоепію і орфографію: "Oh, shut up!" she cried [16, p. 33]. - Ой, замовкни! - закричала вона $[13$, с. 60]. Показовим прикладом другого підходу з опущенням первинного вигуку і передачі смислового навантаження 3 допомогою розділового знаку служить наступний варіант перекладу: Oh the poor thing [16, p. 11]. - Бідолашний! [13, c. 117]. У наступному прикладі вжито вигук, якому притаманна повторюваність, щоб інтенсивніше виразити комунікативну мету і підсилити емоцію зневаги з відтінком іронії: $\mathrm{Oh}, n o$. You never acted in your life, I said [16, p. 53]. Ой-ой-ой, ні, звичайно. Ти ніколи у своєму житті нічого не вдавала [13, с. 91].

Іншим прикладом вигуку, що виконує дифузну семантичну функцію і може виражати найрізноманітніші почуття $\mathrm{e}$ well: Well, you're part of it. Everything free and decent in life is being locked away in filthy little cellars by beastly people who don't care [16, p. 62]. - Нy, ти - частина цього. Усе вільне $і$ пристойне в житті заликають у темні підзелелля жахливі люди, яким до всього байдуже [13, с. 107]. За словником well мае значення "indicating pondering or consideration, sometimes with sarcasm or mock surprise" [15], тобто або нейтральне, або з відтінком сарказму чи невдоволення. Перекладач використовуе відповідник "ну», що в українській також мае відтінок невдоволення. При цьому в обох випадках зберігаеться саме емоція здивування.

Значну за обсягом групу складають вигуки, що служать для вираження негативних емоцій. У наступному прикладі вжито вигукову конструкцію God forbid, яка в українській мові відтворена «Хай Бог милуе»: You could lean on me financially, I said. "And you on me for everything else? God forbid” [16, p. 27]. - Можеш спиратися на мене ббінансово, - запропонував я. - А ти на мене ще якось? Хай Бог милує [13, с. 49]. Згідно з тлумаченнями в англійських і українських словниках дані висловлювання виражають небажаність, заперечення чого-небудь. Це також показуе контекстуальний аналіз. Вислови релігійного характеру в більшості випадків відтворені словниковими або фуннкціональними відповідниками, які відповідають вимогам адекватності перекладу.

До продуктивних лексичних засобів передачі емоційного стану героїв у романі «Колекціонер» належить груба, вульгарна та нецензурна лексика, використання якої викликане певними прагматичними цілями й створюе жвавість та наочність живого мовлення. Звичайно, що значній кількості слів зниженого тону притаманна негативно-емотивна оцінка. У наступному прикладі лексема muck у словнику мае значення "something you consider very unpleasant or very low quality" [15], тобто щось дратівливе та неприемне, а інтенсифікатор such підкреслюе експресивність висловлювання: It's a lovely room. It's wicked to fill it with all this shoddy stuff. Such muck! [16, p. 24]. Така гарна кімната. Просто підлість - напхати ї такою вульгарщиною. Таким лайнол! [13, с. 44]. Вигукова конструкція перекладена функціональним відповідником з урахуванням контексту, експресивного компонента значення та норм української мови. У першому реченні використано лексему shoddy, якій притаманний оцінний компонент і говорить про якісну характеристику суб'єкта, а в перекла- 
ді лексему «вульгарщина», яка містить ощінний компонент, але домінантним $є$ експресивний, який своєю образністю підкреслюе зневажливе ставлення героїні до об'єкта опису.

Деяка переосмислена емотивна лексика абсолютно не збігаються ні за своїм компонентним складом, ні за своїми фрункціонально-семантичними характеристиками в тексті оригіналу та перекладу, однак повністю передає емоційний настрій та лінгвокультурну складову текстової реальності: And David Evans, all white and stammering, don't you tell me my father's a bloody animal I've got to kick out of the way [16, p. 66]. I Девід Еванс аж заїкатися почав, зблід $і$ сказав: "Не кажи мені, бляха-муха, що мій батько тварина, бо зараз я тобі!» [13, с. 115]. У вищенаведеному прикладі конотатив bloody опущено, натомість додано другорядний релевантний для україномовної картини світу елемент «бляха-муха», щоб компенсувати стилістичний ефект. Крім цього перекладач змінив комунікативний тип речення - 3 розповідного на окличне.

Емоції на морфологічному рівні виражаються в словах, емощійне ставлення яких до предмета або явища зумовлене граматичними способами та особливими афіксами [8, с. 78]. Характерним є те, що Міранда часто використовуе неологізми, які виражають її зневагу до Фредеріка. Вони утворені сполученням відомих морфем відповідно до словотворчих моделей, які привертають увагу читача та підсилюють вплив на нього. Подібна ситуативна лексика особливо експресивна, якщо характер об'єднання морфем незвичайний. Перекладачка помітно розширюе висловлювання, застосовуючи описовий переклад: It's his line. The mock-humble. Ever-so-sorry [16, р. 57]. Це його стиль. Удавано скролний. Весь час неловби вибачається [13, с. 98]. Переклад даного прикладу можна вважати адекватним, оскільки переклад повністю відбиває прагматичну установку автора.

На синтаксичному рівні можна відзначити, що в перекладі широко використовуються еліптичні речення, зокрема еліпс підмета, завдяки чому переклад часто набуває більшої виразності, ніж оригінал: "I hate scientists," she said. "I hate people who collect things, and classify things and give them names and then forget all about them. That's what people are always doing in art. They call a painter an impressionist or a cubist or something and then they put him in a drawer and don't see him as a living individual painter any more" [16, p. 24]. - Терпіти не можу вчених, - заявила вона. - Ненавиджу тих, хто збирає шось, класифбікує, дає назви, а тоді все про нього забуває. Так люди роблять і з листецтвол. Називають художника ілпресіоністол, чи кубістол, чи ше якось, тоді кладуть його в таку шухляду $і$ більше не бачать у ньолу живу особистість [13, с. 45]. У поєднанні з лексичним повтором еліпс набуває вищого рівня емоційності I won't die. I won't die. Not for Caliban [16, p. 145]. - Я не noмpy. He noмру. Тільки не заради Калібана [13, с. 200], I hate you, I hate you [16, p. 24]. - Ненавиджу, ненавиджу тебе! [13, с. 38].

Під час аналізу значну кількість номінативних речень було зареєстровано у мові Міранди, що надають їі розповіді динамічності та експресивності. При перекладі таких висловлювань були використані: український аналог - The isolation he keeps me in. No newspapers. No radio. No TV. I miss the news terribly [16, p. 64]. - У якій ізоляиї він мене трилає! Нi газет. Hi радіо. Hi телевізора. Я дико сулую за новинали [13, с. 110]; Hоw I hate ignorance! [16, p. 69]. - Як же я ненавиджу невігластво! [13, с. 119], граматичну заміну You're so stupid. Perverse [16, p. 35]. - Якuй mu дурний! Збоченеиь [13, с. 63]; Blind, blind, other world. Cліпота, сліпота, інший світ [13, с. 105], компенсацію - It would be a real tragedy. Not sordid [16, p. 124]. - То буде справжня трагедія. Без ницості, огиди [13, с. 212]; How he would despise that! [16, p. 67]. 3 якою зневагою він би ие сприйняв, коли б почув! [13, с. 115], дослівний переклад - The time in prison. Endless time [16, p. 56]. Час у в'язнииі. Нескінченний час [13, с. 97].

Висновки і пропозиції. Враховуючи антропоцентричний підхід до вивчення мови, який ставить людину в центр лінгвістичних досліджень, емотивність, як мовне відображення людських почуттів, посідає вагоме місце в мовознавстві останніх десятиліть. Відсутність единої теорії емоцій, універсальної класифікації емоцій і неоднозначність їх позначень створюють певні труднощі для лінгвістів при аналізі їх мовного вираження.

Для досягнення основної мети перекладу художнього твору, а саме створення тексту, який за силою інтелектуального та емоційного впливу на читача максимально відповідає оригіналу, необхідною умовою є прагматична адаптація тексту. Дослідження демонструе, що роман Джона Фаулза «Колекціонер» характеризується високим ступенем емотивності. Аналіз перекладу виявив, що характерними є відхилення від смислової точності з метою забезпечення художності перекладу та збереження комунікативного наміру автора. Серед найбільш репрезентативних засобів передачі емоцій зареєстровано вигуки та вигукові конструкщіі, лайлива лексика, еліпс підмета, різні види повторів, номінативні речення, односкладні неповні та безособові синтаксичні конструкції. Таким чином, можна зробити висновок, що мовні засоби вербалізащії емоцій у художньому дискурсі взаємопов'язані, вони доповнюють одне одного та служать інтенсифрікаторами емоцій, характер яких визначає мета автора та контекст. Засоби лексичного рівня вирізняються етноспецифічністю. Наявність серед конотативних значень слова компонентів оцінності та експресивності ускладнює вибір еквіваленту перекладачем, але дозволяе вибрати стилістично та емоційно доцільне слово. У перекладі було вжито фрункціональні відповідники 3 нейтральною або підвищеною експресивною оцінкою, граматичні та лексичні заміни мовних одиниць для натуралізації висловлювання, дослівний переклад і компенсаторний механізм для відшкодування стилістичних втрат. 3-поміж синтаксичних засобів емотивності в українській мові найбільш успішно як трансформації вживаеться еліпс підмета, що надає тексту виразності.

До перспективних напрямів подальших наукових досліджень у галузі перекладу мовних засобів вербалізації емоцій доцільно віднести питання виявлення різнорівневих репрезентацій категорії емотивності у тексті, їх культурно специфічних особливостей та способів відтворення у перекладі. 


\section{Список літератури:}

1. Александрова О. В. Проблемы экспрессивного синтаксиса : на материале английского языка. Москва, 1984. 212 c.

2. Арнольд И. В. Стилистика. Современный английский язык : учебник для вузов. Москва, 2010. 384 с.

3. Бабенко Л. Г. Лексические средства обозначения эмоций в русском языке. Свердловск, 1989. 184 с.

4. Вежбицкая А. Язык. Культура. Познание. Москва, 1996. 416 с.

5. Изард К. Е. Психология эмоций. Санкт-Петербург, 2000. 464 с.

6. Ионова С. В. Когнитивный подход к исследованию текстовой эмотивности. Вестник ВолГУ. 2000. Вып. 5. C. $116-121$.

7. Комиссаров В. Н. Теория перевода (лингвистические аспекты) : учеб. для ин-тов и фрак. иностр. яз. Москва, 1990. $253 \mathrm{c}$.

8. Кузенко Г. М. Мовні засоби вираження емотивності. Наукові записки НаУКМА. Філологічні науки. 2000. T. 18. C. $76-83$.

9. Модестов В. С. Художественный перевод: история, теория, практика. Москва, 2006. 464 с.

10. Шаховский В. И. Эмотивная семантика слова как коммуникативная сущность. Коллуникативные аспекты значения. Волгоград, 1990. С. 29-40.

11. Шаховский В. И. Стилистика английского языка : учебное пособие. Москва, 2008. 208 с.

12. Шаховский В. И. Лингвистическая теория эмоций : монография. Москва, 2008. 416 с.

13. Фаулз Дж. Колекціонер. Київ, 2015. 304 с.

14. Филимонова О. Е. Эмоциология текста. Анализ репрезентации эмоций в английском тексте : учебное пособие. Санкт-Петербург, 2007. 448 с.

15. Cambridge Dictionary. URL: https://dictionary.cambridge.org/ (дата звернення: 25.11.2021).

16. Fowles J. The Collector. London, 2004. P. 156.

\section{References:}

1. Aleksandrova O. V. (1984) Problemy ekspressivnogo sintaksisa: na materiale angliyskogo yazyka [Problems of expressive syntax: on the material of English language]. Moscow: Vysshaya shkola. (in Russian)

2. Arnold I. V. (2010) Stilistika. Sovremennyy angliyskiy yazyk: uchebnik dlya vuzov [Stylistics. Modern English: a textbook for universities]. Moscow: Flinta. (in Russian)

3. Babenko L. G. (1989) Leksicheskiye sredstva oboznacheniya emotsiy v russkom yazyke [Lexical means of denoting emotions in Russian language]. Sverdlovsk: Ural University. (in Russian)

4. Vezhbitskaya A. (1996) Yazyk. Kultura. Poznaniye [Language. Culture. Cognition]. Moscow: Rucskie slovari. (in Russian)

5. Izard K. E. (2000) Psikhologiya emotsiy [Psychology of emotions]. Sankt-Peterburg: Piter. (in Russian)

6. Ionova S. V. (2000) Kognitivnyy podkhod k issledovaniyu tekstovoy emotivnosti [Cognitive approach to the study of emotivity in text]. Bulletin of Volgograd State University, no. 5, pp. 116-121.

7. Komissarov V. N. (1990) Teoriya perevoda (lingvisticheskiye aspekty): ucheb. dlya in-tov i fak. inostr. yaz. [Translation theory (linguistic aspects): textbook for students and faculty of foreign languages]. Moscow: Vysshaya shkola. (in Russian)

8. Kuzenko H. M. (2000) Movni zasoby vyrazhennia emotyvnosti [Linguistic means of expressing emotivity]. Scientific notes of NaUKMA. Philology, vol. 18, pp. 76-83.

9. Modestov V. S. (2006) Khudozhestvennyy perevod: istoriya, teoriya, praktika [Literary translation: history, theory, practice]. Moscow: Maxim Gorky Literature Institute. (in Russian)

10. Shakhovskiy V. I. (1990) Emotivnaya semantika slova kak kommunikativnaya sushchnost [Emotive semantics of a word as a communicative entity]. Communicative aspects of meaning. Volgograd: Volgograd State Pedagogical University, pp. 29-40.

11. Shakhovskiy V. I. (2008) Stilistika angliyskogo yazyka: uchebnoe posobie [Stylistics of the English language: a study guide]. Moscow: Lybrokom. (in Russian)

12. Shakhovskiy V. I. (2008) Lingvisticheskaya teoriya emotsiy: monografiya [Linguistic theory of emotions: monograph]. Moscow: Gnozis. (in Russian)

13. Faulz Dzh. (2015) Kolektsioner [The Collector]. Kyiv: Klub simeinoho dozvillia. (in Ukrainian)

14. Filimonova O. Ye. (2007) Emotsiologiya teksta. Analiz reprezentatsii emotsiy v angliyskom tekste: uchebnoye posobiye [Emotionology of the text. Analysis of the representation of emotions in the English text: a study guide]. Sankt-Peterburg: Knizhnyy Dom. (in Russian)

15. Cambridge Dictionary. Available at: https://dictionary.cambridge.org/ (accessed 25 November 2021).

16. Fowles J. (2004) The Collector. London: Vintage. 